\title{
Cover crop rotation influence on nutsedge (Cyperus spp.) density and onion yield ${ }^{1}$
}

\author{
Nelson Semidey ${ }^{2}$ and Luisa E. Flores-López ${ }^{3}$
}

J. Agric. Univ. P.R. 90(3-4):215-220 (2006)

\begin{abstract}
Velvet bean [Mucuna deeringiana (Bort.) Meer.], pigeon pea [Cajanus cajan (L.) Huth], sorghum [Sorghum bicolor (L.) Moench.] and tropical pumpkin or calabaza [Cucurbita moschata (Duchesne) Poir.] were evaluated as cover crops for the control of nutsedges in rotation with onion (Allium cepa L.) at the Lajas Agricultural Experiment Station during the years 1998-99 and 1999-2000. In each year of study, the four cover crops were grown until mature stage, and plant residue was disked or removed from soil surface before onion planting. Cover crop species had no significant influence $(\mathbf{P}<$ 0.05 ) on nutsedge density, mainly represented by Cyperus rotundus $L$. and C. esculentus $L$., neither six weeks before onion planting nor after nine weeks of cropping during 1998-99. Disc incorporation of all cover crops suppressed nutsedge density more than removal of plant residues from soil surface. Onion produced greater yield $(30,030 \mathrm{~kg} / \mathrm{ha})$ after calabaza rotation than after pigeon pea $(21,090 \mathrm{~kg} / \mathrm{ha})$ or sorghum $(18,940 \mathrm{~kg} / \mathrm{ha})$ in 1998-99. In 1999-2000, plots grown with velvet bean, pigeon pea and calabaza had less nutsedge than the untreated controls two weeks before incorporation of plant residues. Plots with these three cover crops also had lower density of nutsedges than plots with sorghum. Nutsedge density was not significant at three, six, and 10 weeks after onion planting. In 1999-2000, onion yields among cover crop rotations were not significantly different, with an average of $5,837 \mathrm{~kg} / \mathrm{ha}$. Cover crop allelopathy, as well as nutsedge interference, may have reduced onion production during the second year of planting.
\end{abstract}

Key words: Allium cepa, cover crop, crop rotation, nutsedge, onion

\section{RESUMEN}

Influencia de rotaciones de cultivos cobertores sobre la densidad de ciperáceas (Cyperus spp.) y el rendimiento de cebolla

El haba de terciopelo (Mucuna deeringiana), el gandul (Cajanus cajan), el sorgo (Sorghum bicolor) y la calabaza (Cucurbita moschata) se evaluaron como cultivos cobertores en rotación para el control de ciperáceas en ceboIla en la Estación Experimental de Lajas durante 1998-99 y 1999-2000. Cada año los cultivos cobertores crecieron hasta la etapa de madurez y los residuos vegetativos se incorporaron con rastras de discos o se removieron de la superficie del suelo antes de la siembra de cebolla. Ninguno de los cultivos cobertores influenció significativamente $(P<0.05)$ la densidad de las ciperáceas, mayormente representada por Cyperus rotundus L. y $C$. escu-

${ }^{1}$ Manuscript submitted to Editorial Board 3 February 2006.

${ }^{2}$ Weed Scientist, Crop Protection Department, Agricultural Experiment Station, University of Puerto Rico, HC-01 Box 11656, Lajas, PR 00667.

${ }^{3}$ Research Associate, Agricultural Experiment Station, Lajas, PR. 


\begin{abstract}
lentus $\mathrm{L}$., $\mathrm{ni}$ a las seis semanas antes de la siembra de cebolla, ni nueve semanas más tarde durante 1998-99. La incorporación con discos sobre todos los cultivos cobertores suprimió en mayor proporción la densidad promedio de ciperáceas que la remoción de los residuos vegetativos de la superficie. La cebolla produjo mayor rendimiento con la rotación de calabaza $(30,030$ $\mathrm{kg} / \mathrm{ha}$ ) que con gandul $(21,090 \mathrm{~kg} / \mathrm{ha})$ o con sorgo $(18,940 \mathrm{~kg} / \mathrm{ha})$ en 1998-99. En 1999-2000, las parcelas de cebolla crecidas con haba de terciopelo, gandul y calabaza presentaron densidades de ciperáceas menores que el control sin cultivos cobertores, a las dos semanas antes de incorporar los residuos. En promedio, con estos tres cultivos cobertores también se obtuvo una densidad menor de ciperáceas que con el sorgo. No se encontraron diferencias en la densidad de ciperáceas entre cultivos cobertores a las tres, seis y 10 semanas antes de la siembra de cebolla. En 1999-2000, no hubo diferencias significativas en los rendimientos de cebolla debido a los cultivos cobertores. El rendimiento promedio de cebolla fue de $5,837 \mathrm{~kg} / \mathrm{ha}$. La alelopatía de los cultivos cobertores, así como la interferencia de las ciperáceas, podrían haber reducido la producción de cebolla durante el segundo año de siembra.
\end{abstract}

Palabras clave: Allium cepa, cebolla, ciperáceas, cultivos cobertores, rotación de cultivos

\title{
INTRODUCTION
}

We have established that at least two applications of a postemergence herbicide mixture were needed to achieve an effective control of broadleaf and grass weeds in onion (Semidey and Caraballo, 1989). Conversely, nutsedges (Cyperus spp.) usually remained uncontrolled by registered herbicides, thus interfering with onion yield and harvesting procedures. Studies in Puerto Rico have shown that, in a one-year cropping sequence, velvet bean (Mucuna deeringiana) planted before tomato suppressed purple nutsedge in the tomato crop (Semidey, 1999). Previous studies by Acosta et al. (1991 and 1997) reported a reduction in nematode populations and improvement in soil fertility by velvet bean in a rotation program with tomato.

Cover crops can be used as natural biological agents to control weeds in crops and to reduce the need for herbicides. Cover crops are also recommended for lowering weed competition in fruit crops (Smeda and Weston, 1995). Even though toxicity of plant residues on subsequent crops is considered among the adverse impacts of allelopathy in agriculture (Putnam and Weston, 1986), recent evidence indicates that crop residues when properly managed may suppress certain weed species in cropping systems (Semidey, 1999). The objective of this study was to evaluate velvet bean, pigeon pea (Cajanus cajan), sorghum (Sorghum bicolor), and tropical pumpkin or calabaza (Cucurbita moschata) as rotation cover crops for nutsedge control in onion. This was the first evaluation of calabaza as a weed suppressor in rotation systems under our tropical field conditions. 


\section{MATERIALS AND METHODS}

Four cover crop-onion rotations were established in field plots at the Lajas Agricultural Experiment Station for two consecutive years. The soil is classified as San Antón clay loam (fine-loamy, mixed, superactive, isohyperthermic Cumulic Haplustolls) with $\mathrm{pH} 7.3$ and 2.1\% organic matter content. Velvet bean cv. Florida, pigeon pea cv. Cortada, sorghum cv. FS25A, and calabaza cv. Soler were grown for a few months before onion establishment. The experiment followed a randomized complete block design with four treatments (cover crops) and four replications. Each cover crop was grown in main plots measuring $16.5 \mathrm{~m}$ wide by $4.6 \mathrm{~m}$ long that were later split into three subplots $(5.5 \mathrm{~m}$ wide by $4.6 \mathrm{~m}$ long) for three different plant material incorporation methods: 1) cut and incorporated into soil by disking; 2) cut and removed from soil surface; and 3) untreated control without cover crops, weeded periodically. Onion cv. Texas Grano was direct-seeded both years.

Year 1998-99. The four cover crops were first planted 18 February 1998 and grown under normal cultivation until cut on 11 August. The corresponding subplots were disked twice, in opposite directions on 11 August and 22 December 1998, and 1 February 1999. Onion was seeded 2 February 1999. The whole experimental area was treated three times with a mixture of oxyfluorfen $(0.13 \mathrm{~kg}$ ai/ha $)+$ fluazifop $(0.10 \mathrm{~kg} \mathrm{ai} / \mathrm{ha})+\mathrm{X}-77$ surfactant at $0.5 \% \mathrm{v} / \mathrm{v}$ over-the-top of onion for general weed control during the first nine weeks. Nutsedge density (shoots per square meter), mainly C. rotundus and C. esculentus, was evaluated six weeks before onion planting (WBP), and two, five and nine weeks after planting (WAP). Onion bulbs were harvested 27 May 1999 and graded for marketable yield (bulbs $\geq 100 \mathrm{~g}$ ).

Year 1999-2000. The same cover crops were planted in the corresponding plots 20 August 1999, cut 29 November 1999, and incorporated by following the previously mentioned incorporation procedures 1 December 1999. All plots were disked for a second time 15 December 1999. Onion was direct-seeded 14 January 2000. Herbicide mixture of oxyfluorfen $(0.13 \mathrm{~kg} \mathrm{ai} / \mathrm{ha})+$ fluazifop $(0.10 \mathrm{~kg}$ ai $/ \mathrm{ha})+\mathrm{X}-77$ $(0.5 \% \mathrm{v} / \mathrm{v})$ was sprayed two times during the first six weeks. Nutsedge density was evaluated two weeks before disking (WBD), and three, six and 10 WAP. Onion bulbs were harvested 23 May 2000 and marketable yield was determined as previously described.

\section{RESULTS AND DISCUSSION}

Year 1998-1999. None of the four cover crops influenced nutsedge density at six weeks before onion planting (Table 1). Disc incorporation and removal of cover crops reduced mean density of nutsedge, com- 
TABLE 1. Influence of four cover crops and their incorporation or removal on nutsedge density six weeks before onion planting at Lajas during 1998-99.

\begin{tabular}{|c|c|c|c|c|}
\hline \multirow[b]{2}{*}{ Cover crop } & \multicolumn{3}{|c|}{ Nutsedge density ${ }^{1}$} & \multirow[b]{2}{*}{ Mean } \\
\hline & Incorporated & Removed & Control (Untreated) & \\
\hline & \multicolumn{4}{|c|}{ - Shoots $/ \mathrm{m}^{2}-\ldots$} \\
\hline Velvet bean & 93 & 156 & 195 & 148 \\
\hline Pigeon pea & 161 & 151 & 175 & 162 \\
\hline Sorghum & 75 & 147 & 193 & 138 \\
\hline Calabaza & 152 & 146 & 198 & 165 \\
\hline Mean ${ }^{2}$ & $120 \mathrm{c}$ & $150 \mathrm{~b}$ & $190 a$ & \\
\hline
\end{tabular}

1The interaction of cover crop by incorporation methods was non-significant; means within a column were not significantly different according to LSD test at $\mathrm{P}<0.05$.

${ }^{2}$ Means for incorporation methods followed by different letter were significantly different according to LSD test at $P<0.05$.

${ }^{3}$ Means for cover crops were not significantly different according to LSD test at $\mathrm{P}<0.05$.

pared with that of the untreated control. Disc incorporation suppressed $37 \%$ of nutsedge on average, $16 \%$ more than removal of plant material. Putnam and DeFrank (1983) suggested that surface residues might have both physical and chemical effects on weed growth. Possibly the removal of plant material from soil surface in part reduced the potential allelopathic influence of these four cover crops on nutsedge density. Onion emergence was not influenced by the cover crop rotations after five weeks (data not shown). Further evaluations from two to nine WAP did not show differences in nutsedge density among cover crops and incorporation methods (Table 2). Onion yield recovered after rotation of calabaza was greater than yield obtained after pigeon pea and sorghum rotations. Irrespective of nutsedge interference, it seems that pigeon pea and sorghum rotations had a detrimental effect on onion

TABLE 2. Influence of cover crops on nutsedge density at two, five, and nine weeks after planting (WAP) and onion yield at Lajas during 1998-99.

\begin{tabular}{lcccc}
\hline & \multicolumn{3}{c}{ Nutsedge density } \\
\cline { 2 - 4 } Cover crop & 2 WAP & 5 WAP & 9 WAP & Onion yield \\
\hline & $\ldots \ldots \ldots$ & Shoots $/ \mathrm{m}^{2}$ & $\ldots \ldots \ldots \ldots$ & $\mathrm{kg} / \mathrm{ha}$ \\
Velvet bean & 12 & 16 & 54 & 24,020 \\
Pigeon pea & 13 & 24 & 67 & 21,090 \\
Sorghum & 7 & 14 & 51 & 18,940 \\
Calabaza & 13 & 24 & 75 & 30,030 \\
LSD $(0.05)$ & NS & NS & NS & 6,170 \\
\hline
\end{tabular}


yield. Pigeon pea rotation also had a negative impact on tomato yield (Semidey and Bosque-Vega, 1999), whereas sorghum residues are among those that may release toxic compounds (Narwal, 1999) and may reduce lettuce, radish and tomato stands under field conditions (Putnam and DeFrank, 1983).

Year 1999-2000. The interaction of cover crops and incorporation methods was significant for nutsedge density taken at two WBD (Table 3 ). At this time, velvet bean, calabaza, and pigeon pea vegetation, either disked or removed from the soil surface the previous year, reduced nutsedge density as compared to the density in the respective untreated controls. Sorghum was not effective in suppressing nutsedge in part because of poor germination of seeds and possibly the lower standing biomass produced at the time of incorporation. For this reason, velvet bean $(98 \%)$, pigeon pea $(56 \%)$ and calabaza (60 to $76 \%$ ) were better than sorghum $(\leq 0 \%)$ in reducing nutsedge populations. As compared with density in the untreated control, disc incorporation of cut cover crop vegetation, as well as surface cover crop removal treatment, reduced nutsedge density by $55 \%$.

None of the cover crops influenced nutsedge density in onion at three, six and 10 WAP (Table 4). At 10 WAP, response of the two nutsedge species was similar and ranged from 19 to 31 and 23 to 40 shoots per square meter for C. esculentus and C. rotundus, respectively. Onion emergence was not significantly affected at six WAP (data not shown). Onion yield was generally low and equally influenced by the interference of nutsedges after the four rotations. Allelopathic effects, both from cover crops and nutsedge, may have influenced onion bulb forma-

TABLE 3. Density of nutsedge as influenced by cover crops and incorporation methods two weeks before disking into soil at Lajas during 1999-2000.

\begin{tabular}{lcccc}
\hline & \multicolumn{3}{c}{ Nutsedge density $^{1}$} \\
\cline { 2 - 4 } Cover crop & Incorporated & Removed & $\begin{array}{c}\text { Control } \\
\text { (Untreated) }\end{array}$ & \multirow{2}{*}{ Mean $^{2}$} \\
\hline Velvet bean & $4 \mathrm{c}$ & $6 \mathrm{c}$ & $241 \mathrm{a}$ & $83 \mathrm{~d}$ \\
Pigeon pea & $108 \mathrm{~b}$ & $107 \mathrm{~b}$ & $246 \mathrm{a}$ & $154 \mathrm{~b}$ \\
Sorghum & $257 \mathrm{a}$ & $224 \mathrm{a}$ & $224 \mathrm{a}$ & $239 \mathrm{a}$ \\
Calabaza & $51 \mathrm{c}$ & $87 \mathrm{~b}$ & $217 \mathrm{a}$ & $118 \mathrm{c}$ \\
Mean $^{2}$ & $105 \mathrm{~b}$ & $106 \mathrm{~b}$ & $235 \mathrm{a}$ & \\
\hline
\end{tabular}

${ }^{1}$ Means for the interaction, followed by the same letter were not significantly different according to LSD test at $\mathrm{P}<0.05$.

${ }^{2}$ Means for cover crops and incorporation methods followed by different letter were significantly different according to LSD test at $\mathrm{P}<0.05$. 
TABLE 4. Influence of cover crops on nutsedge density at three dates after onion planting at Lajas during 1999-2000.

\begin{tabular}{lcccc}
\hline & \multicolumn{3}{c}{ Nutsedge density } & \\
\cline { 2 - 3 } Cover crop & 3 WAP & 6 WAP & 10 WAP & Onion yield \\
\hline & 17 & 18 & kg/ha \\
Velvet bean & 25 & 27 & 42 & 5,280 \\
Pigeon pea & 27 & 31 & 70 & 5,590 \\
Sorghum & 21 & 23 & 62 & 5,640 \\
Calabaza & NS & NS & NS & 6,840 \\
LSD $(0.05)$ & & & & NS \\
\hline
\end{tabular}

tion and growth under these rotation conditions. From the field data obtained in these experiments, we cannot determine the specific role of cover crop allelopathy and nutsedge interference over onion yield.

\section{LITERATURE CITED}

Acosta, N., N. E. Vicente, O. Román and R. Vargas, 1997. Soil fertility improvements by Mucuna deeringiana in a rotation program with tomato. Nematropica 26:323.

Acosta, N., O. Román, N. E. Vicente and L. A. Sánchez, 1991. Sistemas de rotación de cosechas y los niveles poblacionales de nematodos. J. Agric. Univ. P.R. 75:399-405.

Narwal, S. S., 1999. Allelopathy in weed management, pp. 203-254. In: S. S. Narwal (ed.). International Allelopathy Update. Volume 2, Chapter 11, Science Publishers, Inc., USA.

Putnam, A. R. and L. A. Weston, 1986. Adverse impacts of allelopathy in agricultural systems, pp. 43-56. In: A. R. Putnam and C. S. Chong (eds.). The Science of Alleopathy. John Wiley and Sons, New York.

Putnam, A. R. and J. DeFrank, 1983. Use of phytotoxic plant residue for selective weed control. Crop Protection 2:173-181.

Semidey, N., 1999. Integration of allelopathic crops in cropping systems, pp. 271-281. In: S. S. Narwal (ed.). International Allelopathy Update. Volume 2, Chapter 134, Science Publishers, Inc., USA.

Semidey, N. and A. Bosque-Vega, 1999. Yield and weed suppression by pigeon pea cultivars in tomato and peppers. J. Agric. Univ. P.R. 83:55-64.

Semidey, N. and E. Caraballo, 1989. Chemical weed management in onions (Allium cepa L.). J. Agric. Univ. P.R. 73:59-65.

Smeda, R. J. and L. A. Weston, 1995. Weed management systems for horticultural crops, pp. 553-601. In: A. E. Smith (ed.). Handbook of Weed Management Systems. USA. 